\title{
Local Cytokine Production in a Murine Model of Escherichia coli Pyelonephritis
}

Hope S. Rugo, "* Peter O’Hanley, * Alex G. Bishop,' Mike K. Pearce,' John S. Abrams,' Maureen Howard," and Anne O’Garra" *Department of Medicine, Microbiology and Immunology, Stanford University, Stanford, California $94305 ;{ }^{\ddagger}$ Cancer Research Institute, University of California San Francisco, San Francisco, California 94143; and the Department of Immunology, DNAX Research Institute of Molecular and Cellular Biology, Palo Alto, California 94304

\section{Abstract}

Cytokines may play an important role in the regulation of host defense against local bacterial infections. We have evaluated the local production of cytokines in a BALB/c mouse model of Escherichia coli pyelonephritis. Kidneys, draining lymph nodes, and spleens, were harvested at specific time intervals after bladder inoculation with $\boldsymbol{E}$. coli corresponding to the stages of renal infection, infiltration, and bacterial clearance seen in this model. The presence of messenger RNA for specific cytokines (interleukins 1 through 6, chemotactic factors, granulocyte and granulocyte macrophage-colony stimulating factor (GM-CSF), tumor necrosis factor (TNF $\alpha$ ) and $\beta$, IFN $\gamma$, transforming growth factor (TGF $\beta$ ), and cytokine synthesis inhibitory factor (CSIF)/IL-10) was determined by polymerase chain reaction (PCR) amplification of reverse transcribed RNA. We have demonstrated mRNA encoding IL-1, IL-6, G-CSF, GMCSF, TNF $\alpha, \mathrm{H} 400$ (a protein homologous to a family of chemotactic factors and identical to MIP-1 $\beta$ ), and CSIF/IL-10 in the kidney at $12 \mathrm{~h}$ and 1,2 , and $3 \mathrm{~d}$ after bacterial challenge. No signal was seen in normal animals or in mice after $5 \mathrm{~d}$. This pattern of cytokine expression was observed only in renal tissues suggesting a localized response. IL-6 was present in the urine at $4 \mathrm{~h}$ with rapid resolution to baseline levels by 24 to 48 h. In contrast, IL-6 was not usually detectable in the serum. TNF $\alpha$ was not detectable in the serum or urine during the course of the infection. By immunohistochemical staining of kidney sections we have shown that IL-6 is produced predominantly by mesangial cells rather than by the inflammatory infiltrate. This study provides additional evidence utilizing novel techniques that specific cytokines are produced locally in response to bacterial infections. The time course of production demonstrated in this model supports the important role of cytokines in natural host resistance to local infection. (J. Clin. Invest. 1992. 89:1032-1039.) Key words: interleukins • sepsis • host defense $\bullet$ immunohistochemistry $\bullet$ mesangium

Portions of this work were presented at the June 1990 Joint Meeting of the American Association of Biochemistry and Molecular Biology and the American Association of Immunology, New Orleans, LA.

Address correspondence to Dr. Hope S. Rugo, Cancer Research Institute, 505 Parnassus Ave., Room M-1282, University of California San Francisco, San Francisco, CA 94143. Dr. Bishop's current address is A. W. Morrow Gastroenterology and Liver Centre, Royal Prince Alfred Hospital, Camperdown, Australia.

Received for publication 23 October 1990 and in revised form 16 August 1991.

J. Clin. Invest.

(c) The American Society for Clinical Investigation, Inc. 0021-9738/92/03/1032/08 \$2.00

Volume 89, March 1992, 1032-1039

\section{Introduction}

Cytokines are believed to play a role in the host response to bacterial infections. Specifically, they have been shown to aid in recruitment and chemotaxis of neutrophils, proliferation and function of other effector cells, and bacterial clearance (13). Numerous studies have described the presence of cytokines and kinetics of their production in overwhelming bacterial systemic and central nervous system infections (4-6). Several inflammatory monokines (e.g., IL-1, IL-6, and tumor necrosis factor-alpha [TNF $\alpha])^{1}$ have been detected in blood or cerebrospinal fluid and appear to contribute to a series of physiological events frequently culminating in death of the host. In contrast, less information has been obtained concerning the role of cytokines in localized bacterial infections that are usually not lifethreatening and are often spontaneously cleared (7-9). In this effective host response cytokines may contribute to the local eradication of bacterial pathogens. IL-6 has been detected in the urine but not serum of mice and humans after bladder inoculation with Escherichia coli, inferring local production of this cytokine in response to mucosal challenge with gram-negative bacteria $(7,8)$. The cellular components responsible for this mucosal production of IL-6 have not been identified.

In this report, we have investigated in detail the local production of multiple cytokines in a murine model of unobstructed, ascending Escherichia coli pyelonephritis. Complete details of this murine model of pyelonephritis that closely parallels the human infection will be presented elsewhere (Rugo, H. S., and P. O'Hanley, manuscript in preparation). Briefly, intravesicular administration of hemolytic $E$. coli strains leads to bacterial invasion of the renal parenchyma by $12 \mathrm{~h}$ after inoculation. Bacterial growth in the kidneys peaks after 2 to 3 days with gradual resolution through day 7. Bacteria are spontaneously cleared from the kidney after day 10 . The histological pattern reveals a modest polymorphonuclear infiltrate surrounding the intrarenal bacteria at $12 \mathrm{~h}$ with peak inflammation after 2 to $3 \mathrm{~d}$ associated with microabscesses and local necrosis. The infiltrate gradually resolves and is characterized by mononuclear cells after day 5 . The kidneys appear normal after day 14 without evidence of scar formation.

Local production of multiple cytokines was evaluated by the detection of amplified cytokine specific messenger RNA (mRNA) transcripts and immunohistochemical staining of IL6 in tissue sections. Serum and urine levels of IL-6 and TNF $\alpha$ were also determined. This study represents an extensive and detailed analysis of the local renal cytokine response to bacterial infection using novel techniques. These results provide additional information necessary to identify effective mechanisms of host resistance to bacterial mucosal infections and

1. Abbreviations used in this paper: $\mathrm{CF}$, cerebrospinal fluid; $\mathrm{PCR}$, polymerase chain reaction; MIP, macrophage inhibitory protein; TNF, tumor necrosis factor. 
determine potential pathways to modulate the immune response.

\section{Methods}

Experimental pyelonephritis. E. coli $\mathrm{J} 96$ strain $(\mathrm{O} 4, \mathrm{~K} 6)$, a human pyelonephritis isolate, is globoside-binding, hemolytic, colicin V-positive, motile, and resistant to the bactericidal action of normal serum (10). 8-10-wk-old female BALB/c mice (Simonsen Laboratories, Gilroy, CA) were inoculated intravesicularly with $10^{8}$ organisms of J96 strain in $100 \mu \mathrm{l}$ of saline as previously described (10). Time intervals for RNA analysis were chosen to correlate with specific stages of infection, leukocyte infiltration, and bacterial clearance. Time points included the following: $12 \mathrm{~h}$ and $1,2,3,5,10$, and $14 \mathrm{~d}$ after bacterial inoculation. All time points were evaluated at least twice in separate experiments. A total of 10 to 20 mice were killed at each time point. Kidneys, draining paraaortic lymph nodes and spleen were harvested in a sterile manner, flash frozen in liquid nitrogen, and stored at $-80^{\circ} \mathrm{C}$. Before freezing, kidneys were cut sagitally through the midpelvis and the cut surface was swabbed with a sterile swab. The swab was inoculated into trypticase soy broth and incubated with shaking at $37^{\circ} \mathrm{C}$ overnight. The broth was then plated onto MacConkey agar plates, incubated for $24 \mathrm{~h}$ and observed for growth. The J96 strain was confirmed by slide agglutination with anti-O J96 sera (10). Controls for urine studies included animals that received intravesical saline alone; controls for RNA analyses included batch matched animals.

Assay for IL-6 and TNF $\alpha$ in urine and serum. Urine and serum were obtained at $2,4,6,12,16,24,48 \mathrm{~h}$, and $5 \mathrm{~d}$ after bacterial inoculation. IL- 6 levels in the urine and serum and TNF $\alpha$ levels in the urine were determined by immunoenzymatic assay (11) using rat anti-mouse monoclonal antibodies to IL-6 and TNF $\alpha$ (12). The detection limit for these assays is $100 \mathrm{pg} / \mathrm{ml}$. Serum TNF $\alpha$ levels were measured using the Walter and Eliza Hall Institute (WEHI) 164.13 fibrosarcoma bioassay as previously described (13). The limit of detection for TNF $\alpha$ in this system is $1 \mathrm{pg} / \mathrm{ml}$.

RNA analysis. Organs and lymph nodes were crushed while frozen in liquid nitrogen with a sterile mortar and pestle. The frozen powder was then suspended in guanidinium isothiocyanate, layered onto cesium chloride and RNA was harvested as described (14). RNA concentrations were estimated by spectrophotometry at $260 \mathrm{~nm}$. First strand cDNA was synthesized using Abelson Maloney Virus (AMV) reverse transcriptase (Boehringer Mannheim, Indianapolis, IN) and oligo(dT) (Pharmacia Fine Chemicals, Piscataway, NJ) according to the method of Krug et al. (15). $1 \mu \mathrm{g}$ of total RNA was reverse-transcribed for each sample and the control cell line, and $1 / 20$ of this mixture was amplified via the polymerase chain reaction (PCR) as described (16). The sequence of PCR amplification was 35 cycles of denaturation at $94^{\circ} \mathrm{C}$ for $30 \mathrm{~s}$, annealing at $55^{\circ} \mathrm{C}$ for $30 \mathrm{~s}$, and extension at $72^{\circ} \mathrm{C}$ for $1 \mathrm{~min}$. At the end of 35 cycles the reaction was continued with an extension incubation at $72^{\circ} \mathrm{C}$ for $7 \mathrm{~min}$. Amplified products were visualized by ethidium bromide staining of acrylamide gels. Specific amplification was determined by the size of the product on the gel relative to known markers, and confirmed by probing Southern blots with radiolabeled oligonucleotides internal to the amplified product. To ensure equal recovery of RNA, PCR amplification of hypoxanthine phosphoribosyl transferase was performed. All amplifications were repeated at least twice and on two separate reverse transcriptions. Negative controls included amplification of a reverse transcription mixture incubated without reverse transcriptase to assess the presence of contaminating genomic or plasmid DNA in the RNA samples, and amplification of the reaction mixture without cDNA to assess contamination at a later stage. Only samples free of contaminating DNA were used.

PCR primers. Amplification for specific cytokines including interleukins 1 through 6, granulocyte-colony stimulating factor, granulocyte macrophage-colony stimulating factor, TNF $\alpha$, TNF $\beta$ (lymphotoxin or $\mathrm{L} / \mathrm{T}$ ), and IFN $\gamma$ was performed using synthetic oligonucleotide primers as described by Murray et al. (17) and O'Garra et al. (18). The sequences of additional primers for TGF $\beta, \mathrm{H} 400, \mathrm{P} 500$, TY5, and
Table I

\begin{tabular}{|c|l|}
\hline CYTOKINE & SEQUENCE \\
\hline $\begin{array}{c}\text { H400 - sense } \\
\text { - antisense }\end{array}$ & 5'TCCTGCTGTTTCTCTTACACCTCCC3' \\
5'GCTGCTCAGTTCAACTCCAAGTCAC3' \\
\hline $\begin{array}{c}\text { P500 - sense } \\
\text { - antisense }\end{array}$ & 5'ACCTTGAAGAAAGAGCTTCCCCTGA3' \\
5'AGAAGACACGGACAAGGACCTTGGT3' \\
\hline $\begin{array}{c}\text { TY5 - sense } \\
\text { - antisense }\end{array}$ & 5'TITGAAACCAGCAGCCTTTGCTCCC3' \\
\hline 5GFB - sense & 5'GCAGAAAACAGCTTATAGGAGATGG3' \\
- antisense & 5'CAAGGACCTTGCTGTACTGACAGCAAAGG' \\
\hline CSIF/IL-10 - sense & 5'GAAGCTTCTATTCTAAGGCTGGCC3' \\
- antisense & 5'CTGAGCTGCTGCAGGAATGATCATC3' \\
\hline
\end{tabular}

cytokine synthesis inhibitory factor (CSIF/IL-10) are listed in Table I. H400, P500, and TY5 belong to the 'sis' family of small inducible peptides and were deduced from cDNA cloned from concanavalin A activated mouse helper T cells (19). CSIF/IL-10 was isolated and its DNA cloned from activated TH2 type helper T cells (20). This novel cytokine has been shown to inhibit the synthesis and secretion of IFN $\gamma$ in TH1 type T cells (21).

Immunohistochemical staining. The method for immunohistochemical staining has been previously described (22). A modified procedure was employed for identification of cytokines in tissue sections (23). Kidney tissue from mice inoculated with $\mathrm{J} 96$ strain 12, 24, and 48 h previously was snap frozen in liquid nitrogen and embedded in Tissue Tek II (Miles Labs, Naperville, IL). $5 \mu \mathrm{m}$ sections were cut and placed onto gelatin coated slides, air-dried for $20 \mathrm{~min}$, fixed in $4 \%$ para-formaldehyde in $0.1 \mathrm{M}$ phosphate buffered saline (PBS) for 10 min at $4^{\circ} \mathrm{C}$, then washed in PBS. Nonspecific staining was blocked by incubation in $10 \%$ normal mouse serum in PBS for $30 \mathrm{~min}$. Rat monoclonal antibody to mouse IL-6 (clone $40 \mathrm{~F} 11$ ) (12) at $20 \mu \mathrm{g} / \mathrm{ml}$ in $3 \%$ ovalbumin (Sigma Chemical Co., St. Louis, MO) in PBS, was incubated on sections at $4^{\circ} \mathrm{C}$ overnight, then for $1 \mathrm{~h}$ at room temperature. Slides were washed in PBS and then incubated for $15 \mathrm{~min}$ with affinity purified mouse antiserum to rat immunoglobulin $F\left(a^{\prime}\right)_{2}$ fragment (Jackson ImmunoResearch, Avondale, PA) at a 1:50 concentration in $5 \%$ human AB blood group serum in PBS. After washing in PBS, the sections were incubated for $15 \mathrm{~min}$ with rat peroxidase-anti-peroxidase complexes (Jackson ImmunoResearch) at a 1:50 dilution, then washed in PBS. Slides were stained with diaminobenzidine substrate and counterstained as described (22). The control for cytokine staining included normal mouse kidney tissue stained with anti-IL-6 antibody. Specificity was established by completely blocking anti-IL-6 antibody staining by adding an excess of IL- 6 protein to the initial incubation. Slides were examined by light microscopy for peroxidase staining.

Identification of membrane molecules defining infiltrating leukocyte subpopulations was performed on acetone-fixed cryostat sections from kidneys 12 to $48 \mathrm{~h}$ after inoculation. Primary antibodies employed and their specificities were as follows: RB6/8C5 (granulocytes), B220/6B2 (B cells), Lyt-1/53.7.3 (CD5 on T cells and a subpopulation of B cells); L3T4/GK1.5 (CD4 T cells); Lyt 2/53.6.7 (CD8 T cells) (Becton Dickinson, Mountain View, CA), and Mac 1/M1/70 (complement receptor type 3 on macrophages and neutrophils) (24). Antibodies $(10 \mu \mathrm{g} / \mathrm{ml})$ were incubated on sections for $30 \mathrm{~min}$. The slides were then washed and incubated with mouse anti-rat IgG (Jackson ImmunoResearch) at a 1:10 dilution, stained, and counterstained as described above. Controls included staining with appropriate rat isotype control antibodies. Slides were examined by light microscopy for peroxidase staining.

\section{Results}

Local cytokine production in murine E. coli pyelonephritis. Induction of cytokine specific messenger RNA was evaluated to determine the local cytokine response to this infection. Ampli- 
fication of kidney cDNA revealed a reproducible time course of gene expression for IL-1, IL-6, G-CSF, GM-CSF, TNF $\alpha$, H400, and CSIF/IL-10 (Fig. $1, A$ and $B$ ). Infected kidneys expressed mRNA for these cytokines at $12 \mathrm{~h}$ and 1,2 , and $3 \mathrm{~d}$ following bacterial challenge. There was no signal or minimal signal seen for these cytokines after $5 \mathrm{~d}$, no signal was seen at 10 or $14 \mathrm{~d}$. No signal was seen in normal controls. The only excep-
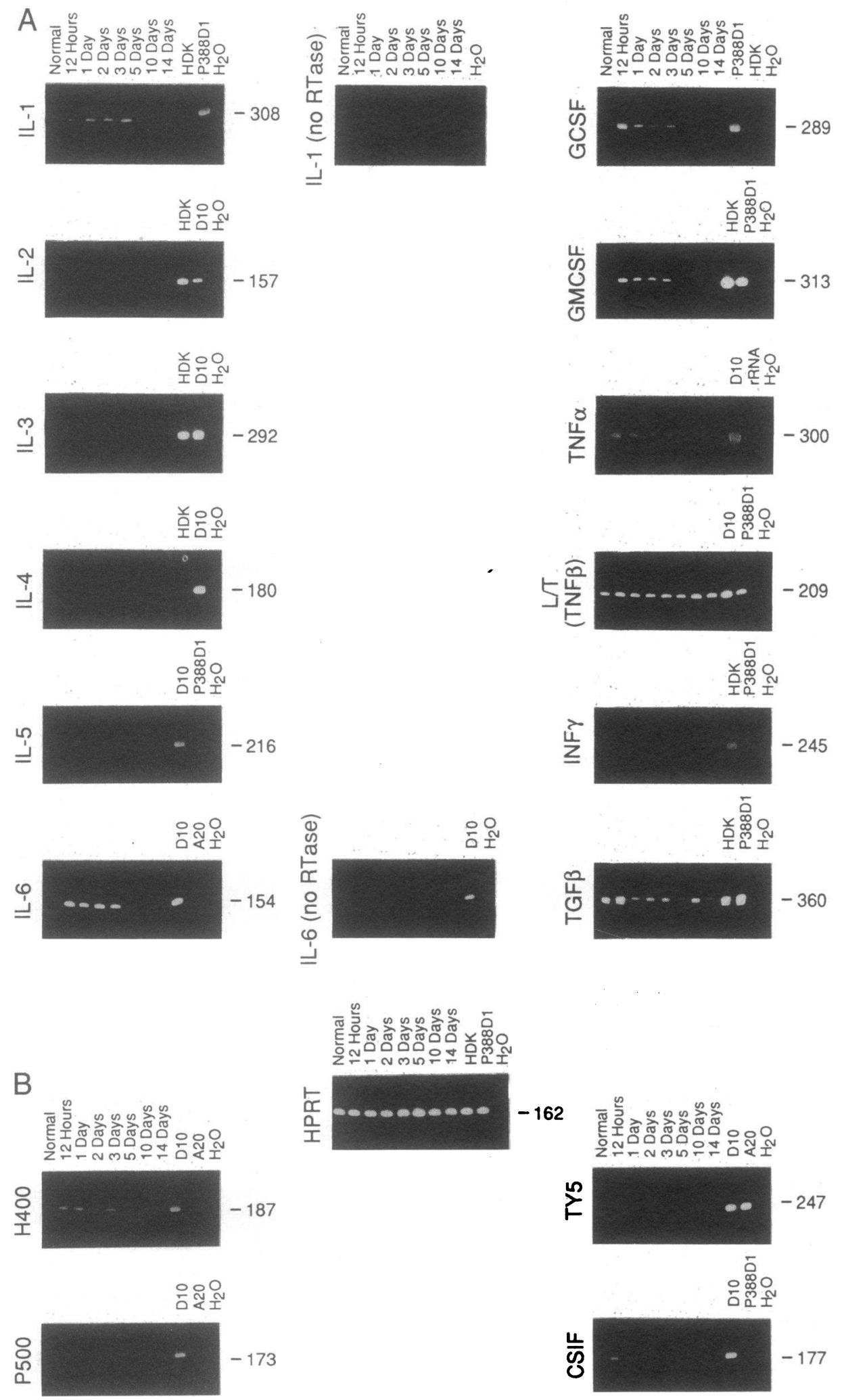
tion. tion was a weak signal for TNF $\alpha$ in normal controls and in mice 10 to $14 \mathrm{~d}$ after inoculation. RNA for the cytokines IL-2, $3,4,5$, P500, and TY5 was not detectable at any time point among infected mice or in normal controls. Constitutive production was seen for lymphotoxin and transforming growth factor $\beta$, and weak production of IFN $\gamma$ was seen only midinfec-

Figure 1. Analysis of cytokine production within the kidney at various time points after bladder inoculation with $E$. coli by polymerase chain amplification of reverse transcribed RNA. Amplified fragments were detected at expected sizes by ethidium bromide staining of $5 \%$ polyacrylamide gels. Cell line controls included HDK1 (a TH1 type T cell line), D10 (a TH2 type T cell line), P388D1 (a macrophage line), and A20 (a B cell lymphoma). ( $A$ ) Amplification of interleukins 1 through $6, G$ and GM-CSF, TNF $\alpha$, TNF $\beta$, IFN $\gamma$, and TGF $\beta$. No R/Tase are non-reverse transcribed controls for IL-1 and IL-6. (B) Amplification of novel cytokines: H400, P500, TY5, and CSIF (see text for explanation). Signals are shown relative to HPRT. 
In contrast to the cytokine production detected within the kidney, no induction of cytokine mRNA was seen in the draining lymph node preparations. Analysis of spleen samples from infected and normal mice revealed only weak constitutive production of IL-6, TNF $\alpha$, TNF $\beta$ and IFN $\gamma$ (data not shown). These data suggest that there is a localized cytokine response to bacterial infection of the kidney. The cytokine response is confined to the kidney and does not involve extrarenal lymphoid organs.

The presence of IL- 6 and TNF $\alpha$ proteins in the serum and urine was assessed from 2 to $48 \mathrm{~h}$ after infection. Earlier time points ( 2 to $12 \mathrm{~h}$ ) were included because of recent data showing the rapid production and disappearance of inflammatory cytokines after systemic or local bacterial challenge $(4,7,25)$. IL-6 levels in the urine appeared as early as $4 \mathrm{~h}$ after inoculation and peaked at approximately 6 to $12 \mathrm{~h}$ after inoculation with gradual resolution over 24 to $48 \mathrm{~h}$. The levels from six infected mice and sham catheterized controls are shown in Fig. 2. Serum IL-6 levels were occasionally elevated above background as early as $2 \mathrm{~h}$ after inoculation, but this response did not correlate with the levels of urine IL-6. There were extremely variable background levels of serum IL-6. IL-6 was not detectable in the urine of control animals. TNF $\alpha$ was not detected in the serum $(<1 \mathrm{pg} / \mathrm{ml})$ or urine $(<100 \mathrm{pg} / \mathrm{ml})$ of mice challenged with bacteria.

Immunohistochemical staining of IL-6. Kidney sections were stained for IL-6 at $12 \mathrm{~h}$ and 1 and $2 \mathrm{~d}$ after intravesicular bacterial inoculation (Fig. 3). Intense glomerular staining for IL-6 was seen at all time points examined after bacterial challenge. The distribution of IL-6 staining was characteristic of mesangial cell localization (Fig. 3, $B$ and $C$ ). There was no IL-6
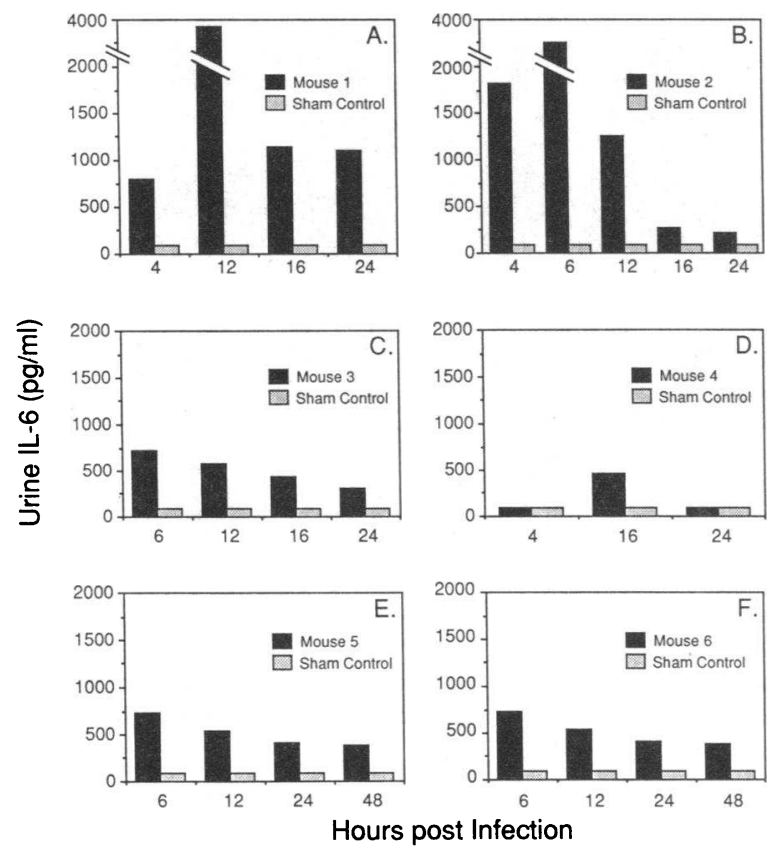

Figure 2. Analysis of urine IL-6 by immunoenzymatic assay. A through $\mathrm{F}$ represent individual mice at various time points after bladder inoculation with $E$. coli. Each sample was compared to urine IL-6 values from sham catheterized mice at the same time points. Concentrations of IL- 6 were determined by comparison to a murine recombinant IL-6 standard. staining seen in the normal kidney. Glomerular staining for IL-6 in infected mice was completely blocked by the addition of IL-6 protein to the tissue sections, confirming the specificity of staining for IL-6 (data not shown). In addition, there did not appear to be significant IL-6 production by the cells composing the inflammatory infiltrate in the infected kidney (Fig. $3 \mathrm{D}$ ).

Pathology of murine E. coli pyelonephritis. The cellular basis for local cytokine production from 12 to $48 \mathrm{~h}$ after inoculation was assessed by immunohistochemical staining for cell surface markers in the kidney. Staining at $12 \mathrm{~h}$ after $E$. coli bladder inoculation revealed moderate focal infiltrates of neutrophils and possibly macrophages within the renal medulla and pelvis (cells stained with RB6/8C5 and Mac 1). The extent and intensity of these infiltrates increased up to $48 \mathrm{~h}$ after bacterial inoculation (Fig. 4). The 48-h infiltrate did not contain cells expressing CD4 (Fig. 4), CD8, Ly-1, and B220.

\section{Discussion}

This study demonstrates that mRNA for TNF $\alpha$, IL-1, IL-6, G-CSF and GM-CSF, H400, and CSIF/IL-10, is expressed locally in the kidney in response to $E$. coli pyelonephritis. The time course of expression for these cytokines differs significantly from that of an overwhelming systemic or central nervous system bacterial infection $(4,25)$. In addition, it appears that production of IL-6 that is released into the urine in response to this infection is independent of serum levels, and that this cytokine may be produced within the glomerulus. The site of production of additional cytokines seen in this model is under investigation.

Previous investigators employing a murine model of $E$. coli pyelonephritis have described the presence of IL-6 in the urine as early as $2 \mathrm{~h}$ after inoculation but did not extend their study to the localization of cytokine production (7). IL-6 is found in the urine and not serum of both human volunteers and mice after intravesical challenge with gram-negative bacteria $(7,8)$. High bacterial counts in the kidney and persistent infection in the murine study were found to correlate with higher urine IL-6 levels but not with serum IL-6 levels. In this study the peak concentration of IL-6 in the urine appeared to roughly correlate with the appearance of mRNA in the kidney for that cytokine. IL-6 levels in the serum did not correlate with levels in the urine in animals clearing the infection also suggesting a local source of production under independent control. RNA analysis extends these observations to include multiple cytokines that are produced in response to this local infection.

Inflammatory cytokines have also been evaluated in the serum, cerebrospinal fluid (CF), and pleural fluid after bacterial challenge. The serum levels of IL-1, IL-6, and TNF $\alpha$ have been shown to correlate with death in meningitis (5) and in infectious purpura (6). In these studies, peak levels of TNF $\alpha$, IL-1, and IL-6 occur within $3 \mathrm{~h}$ of bacterial challenge $(4,25)$. Protein production has previously been shown to correlate with mRNA expression (26). Recently, production of these cytokines in the CF has been shown to be independent of serum levels in response to challenge with lipopolysaccharide (4). Local production of TNF and IFN- $\gamma$ by pleural tissue in tuberculous pleuritis has been described and is thought to play an important role in the local tissue response to this chronic infection (9). In addition, human synovial cells and fibroblasts have been shown to produce inflammatory cytokines which may be involved in the pathogenesis of chronic arthropathies (27). There 


\section{A}

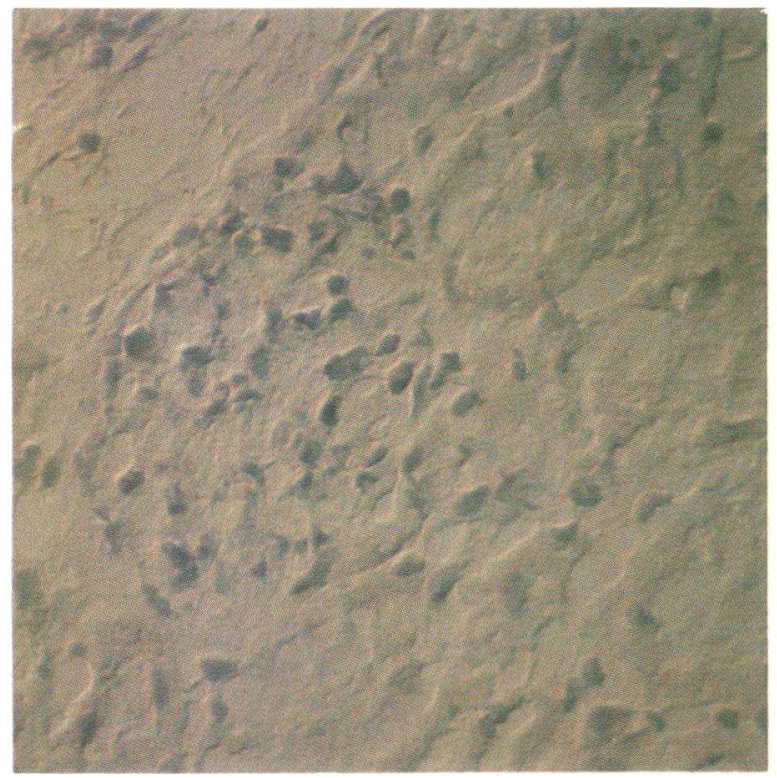

C

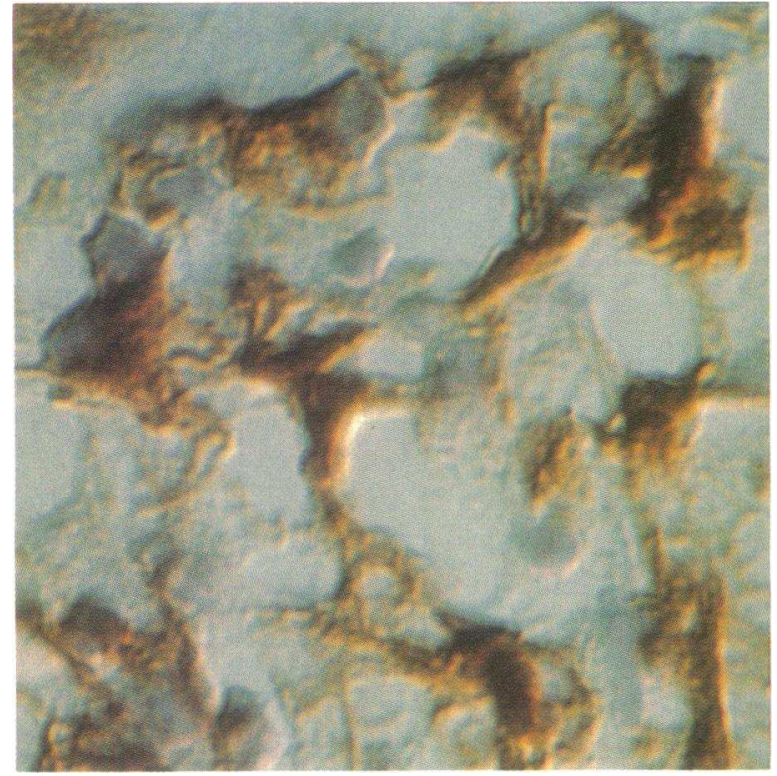

B

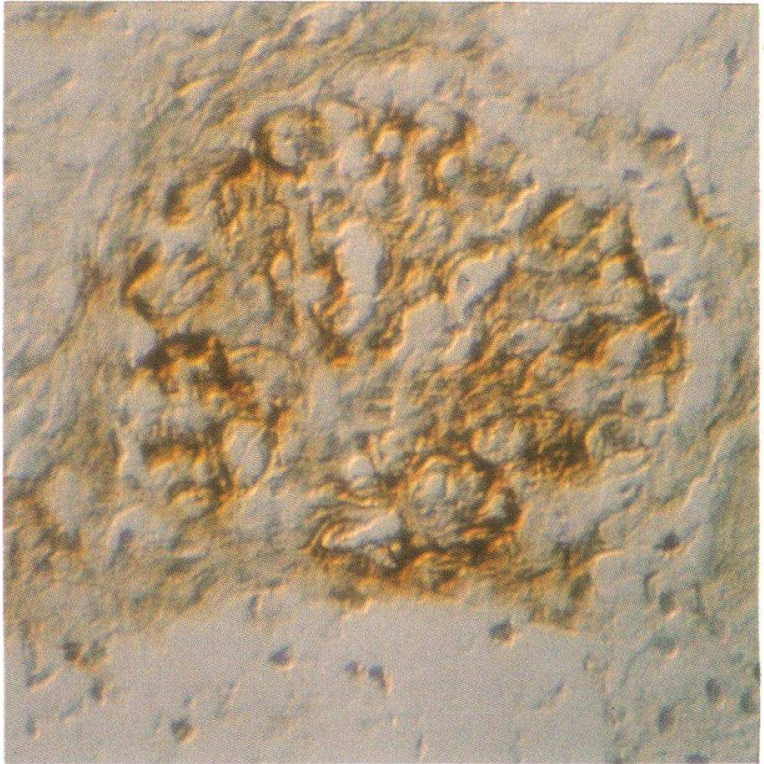

D

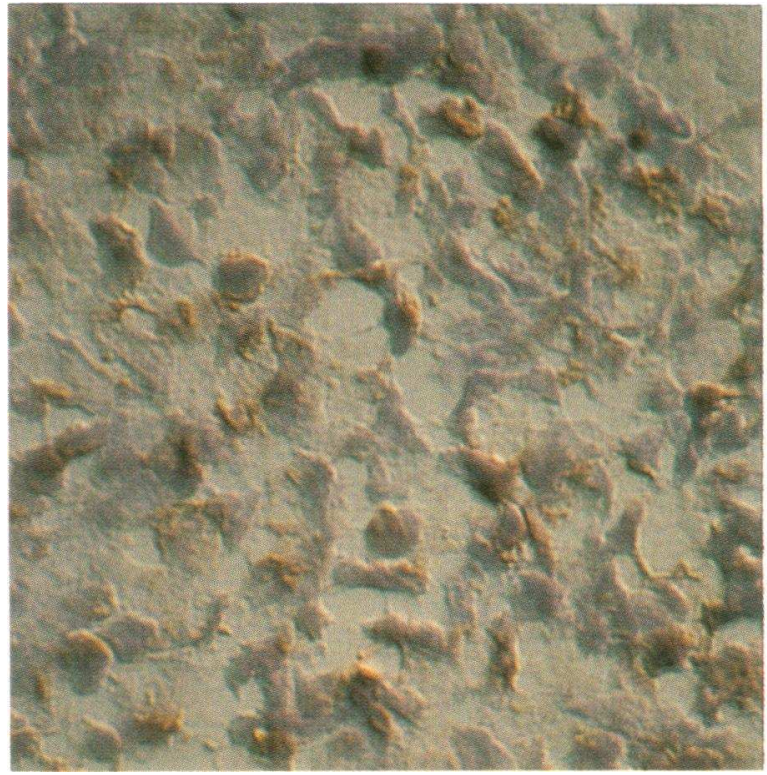

Figure 3. Immunohistochemical analysis of IL-6 producing cells within the kidney. Sections were stained with rat monoclonal antibody (IgM) to mouse IL-6, developed with peroxidase-anti-peroxidase and counterstained with Mayer's hematoxylin. $(A)$ Normal kidney section (final magnification $\times 300$ ). $(B)$ Kidney section $24 \mathrm{~h}$ after bladder inoculation with $E$. coli showing intense staining of the mesangial cells within the glomerulus (final magnification $\times 480$ ). (C) Magnification of mesangial cells $24 \mathrm{~h}$ after bladder inoculation with $E$. coli showing intense staining with anti-IL-6 antibodies (final magnification $\times 1536$ ). $(D)$ Kidney section $24 \mathrm{~h}$ after bladder inoculation with $E$. coli showing minimal staining of the cells composing the infiltrate (final magnification $\times 960$ ). Sections were photographed with a blue filter.

may be many different compartments within the body with respect to cytokine production and kinetics. Moreover, the effects of locally produced cytokines may not correlate with the effects seen as a result of circulating cytokines.

Mesangial cells have been shown to produce IL-1 (28), GM-
CSF (29), TNF $\alpha$ (30), and IL-6 in culture, and IL-6 in vivo in mesangial proliferative glomerulonephritis (31). IL-1 and IL-6 induce rat mesangial cell proliferation in vitro $(31,32)$ suggesting that these cytokines may play a pathogenic role as autocrine growth factors in chronic proliferative diseases of the mesan- 
A

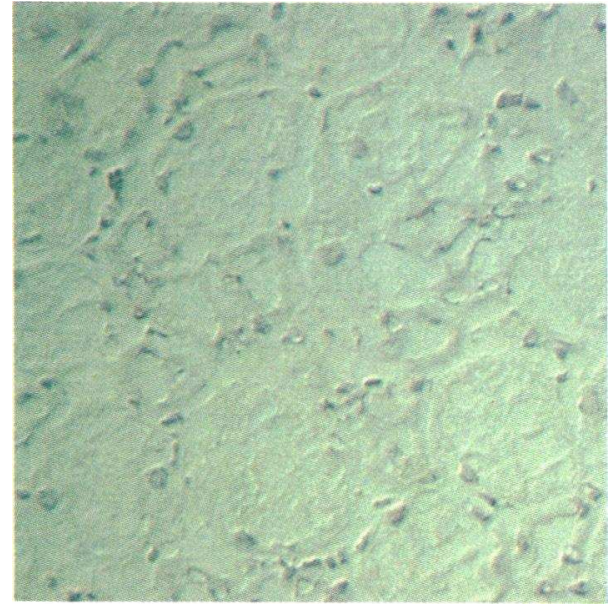

C

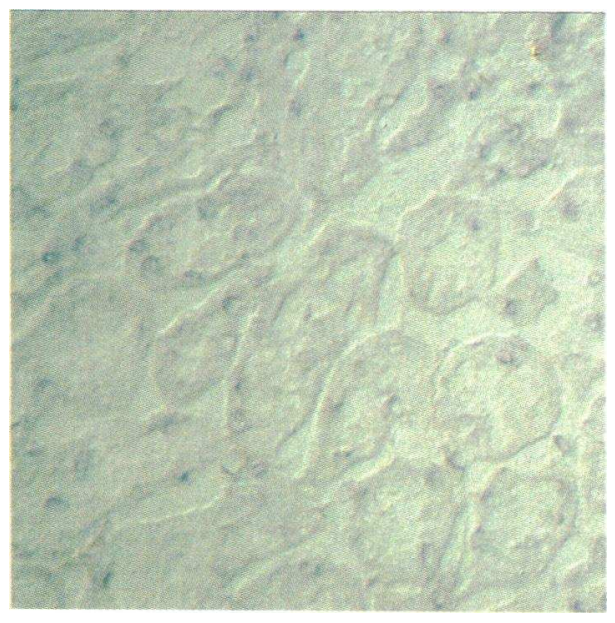

E

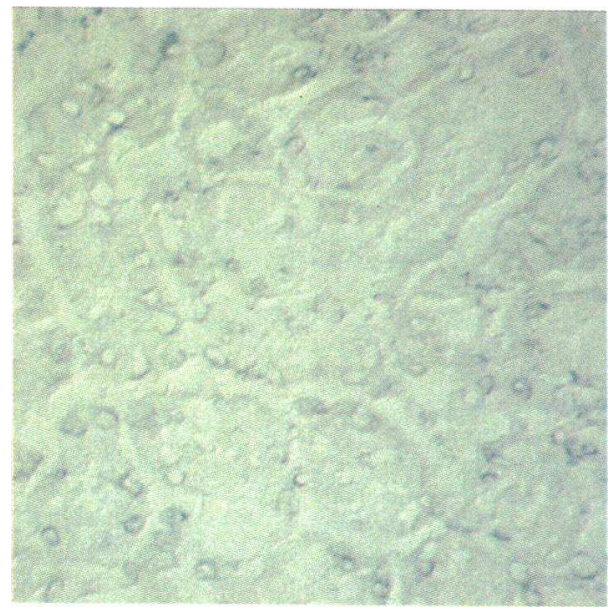

B

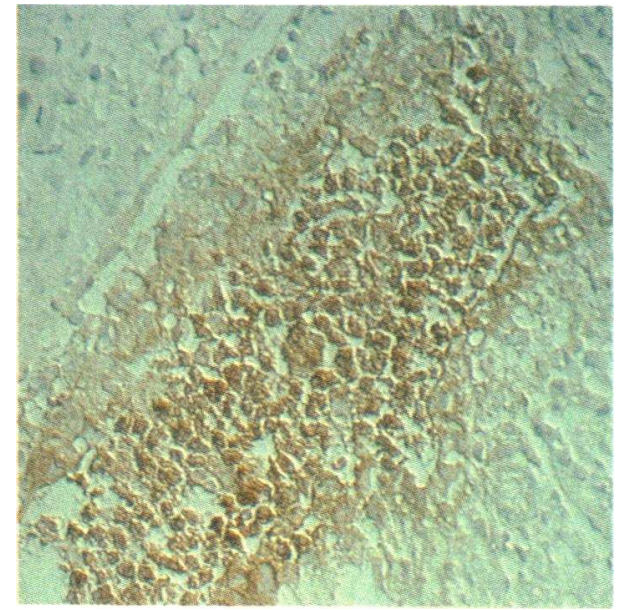

D

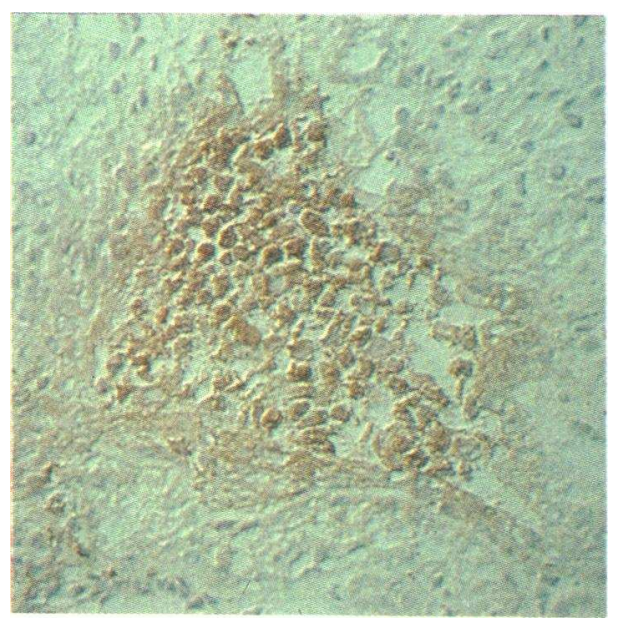

F

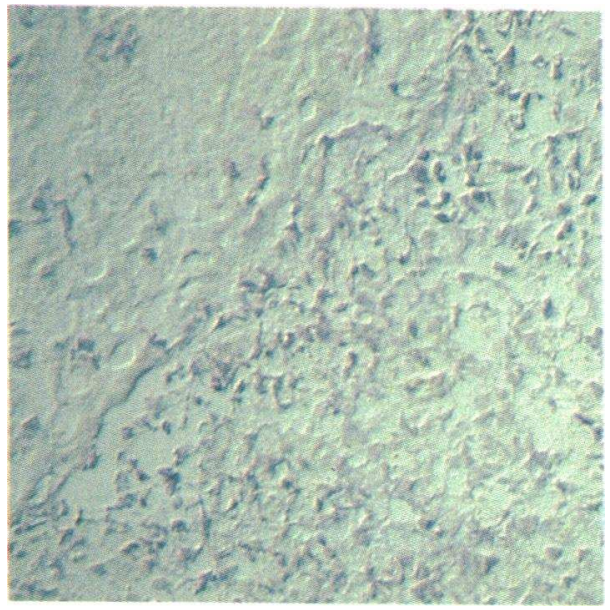

Figure 4. Immunohistochemical analysis of cell membrane markers in the kidney. $(A, C, E)$ Sections of normal kidney stained with $(A)$ Mac-1 (macrophages and neutrophils), $(C)$ RB6/8C5 (neutrophils), and $(E)$ CD4, respectively. $(B, D, F)$ Sections of kidney $48 \mathrm{~h}$ after $E$. coli bladder inoculation stained with (B) Mac-1, (D) RB6/8C5, and $(F) C D 4$, respectively. Slides were photographed with a blue filter. Final magnification of photomicrographs $A$ to $F, 600$. 
gium. In this study we have shown that glomerular cells produce IL-6 in vivo in response to local bacterial infection. The role of IL-6 in eradicating local infections is unclear. Blunting the urinary IL-6 response with pharmacologic inhibitors and cyclosporin A has not been shown to result in decreased clearance of bacteria from the urinary tract in 24-h experiments (33, 34). It is possible that low levels of IL-6 are sufficient to aid in bacterial clearance, or that the IL-6 effect is more important for late clearance (later than $24 \mathrm{~h}$ after inoculation) of bacteria from the kidney. Although pyelonephritis is an infection that usually involves the distal tubules and collecting ducts in the pelvis and medulla of the kidney, it is of interest that the glomerulus is the site of production of IL-6. Hence, the role of IL-6 in this infection may be to regulate the local immune response at other sites within the kidney. Autocrine stimulation of mesangial cell proliferation may be triggered by an acute event such as pyelonephritis and lead to a chronic proliferative syndrome characterized by progressive renal insufficiency. Modulation of this abnormal proliferation may be possible by understanding the local host defense to acute injury.

The sequential release of TNF $\alpha$, IL-1, and IL- 6 has been demonstrated in the serum and CF of patients with meningococcal infections $(4,5)$. In addition, a recent study has shown that antibodies to TNF $\alpha$ reduce IL- 1 and IL- 6 appearance during lethal bacteremia suggesting that TNF $\alpha$ is an essential stimulus for the release of these inflammatory cytokines during septic shock (25). However, Havell and Sehgal (35) investigated the role of TNF in stimulating IL-6 production in response to a Gram-positive bacterial infection with Listeria monocytogenes. Passive immunization of mice with anti-TNF antibodies before bacterial challenge resulted in complete blunting of the TNF response but no change in the markedly elevated levels of IL-6 in the serum and spleen, implying TNFindependent IL- 6 production. In the current study, TNF $\alpha$ protein was not detected in the urine or serum as early as two $h$ after infection although mRNA for this mediator was detectable by PCR. This suggests that the mechanism of mesangial IL-6 production in $E$. coli pyelonephritis may also be independent of systemic TNF $\alpha$.

H400, TY5, and P500 are members of a family of small inducible peptides (19). H400 is identical to another recently described factor, macrophage inflammatory protein- $1 \beta$ (MIP$1 \beta)(36)$, and TY5 is identical to MIP-1 $\alpha$ (37). Injection of MIP-1 in vivo has been shown to enhance chemotaxis of neutrophils and monocytes and MIP-1 can also serve as a pyrogen in a prostaglandin-independent manner (38). The time course of RNA production for $\mathrm{H} 400$ demonstrated in this model appears to further support the importance of MIP-1, particularly MIP-1 $\beta$, in the in vivo induction of local inflammation. The known cell sources of MIP- $1 \alpha$ and $\beta$ are T cells and macrophages. Further investigation of the pyelonephritis model is needed to determine the cell type responsible for MIP-1 $\beta$ (H400) production in the inflamed kidney.

In conclusion, this study has outlined a time sequence for cytokine RNA expression and IL-6 production following experimental $E$. coli pyelonephritis in a murine model. This time sequence differs from that described in a systemic or central nervous system infection. The renal cytokine RNA expression in this infection parallels the appearance of the inflammatory infiltrate and disappears as the inflammation and infection clears. Concentrations of IL-6 in the urine do not correlate with serum levels, as shown in prior studies. Immunohistochemical staining in this investigation provides the additional new information that IL-6 is produced within the glomerulus in this infection. This study provides confirmatory evidence that the kidney is a separate compartment with regard to cytokine production in response to local infection, and suggests that mesangial cells might play an important role in the pathogenesis of acute as well as chronic renal disease.

\section{Acknowledgments}

The authors thank Dr. Christine Martens (Department of Immunology, DNAX Research Institute, Palo Alto, CA 94304) for her invaluable help and for her generous gift of specific PCR primers. The authors also thank Dr. David H. Lovett (Department of Medicine, University of California San Francisco) for his tremendous help with photography as well as his enthusiasm and willingness to donate his time toward the success of this manuscript.

This work was supported by National Institutes of Health (HL07100 and AI-23435) and Schering-Plough Corporation, Kenilworth, NJ.

\section{References}

1. Tracey, K. J., and A. Cerami. 1989. Cachectin/tumor necrosis factor and other cytokines in infectious disease. Curr. Opin. Immunol. 1:454-461.

2. Verghese, M. W., and R. Snyderman. 1990. Role of chemotactic and inflammatory cytokines. In Immunophysiology: The Role of Cells and Cytokines in Immunity and Inflammation. J. J. Oppenheim and E. M. Shevach, editors. Oxford University Press, Inc., New York. 274-284.

3. Kishimoto, T., and T. Harano. 1988. Molecular regulation of B lymphocyte response. Annu. Rev. Immunol. 6:485-512.

4. Waage, A., A. Halstensen, R. Shalaby, P. Brandtzaeg, P. Kierulf, and T. Espevik. 1989. Local production of tumor necrosis factor $\alpha$, interleukin 1, and interleukin 6 in meningococcal meningitis: relation to the inflammatory response. J. Exp. Med. 170:1859-1867.

5. Waage, A., P. Brandtzaeg, A. Halstensen, P. Kierulf, and T. Espevik. 1989. The complex pattern of cytokines in serum from patients with meningococcal septic shock. Association between interleukin 6, interleukin 1, and fatal outcome. J. Exp. Med. 169:333-338.

6. Girardin, E., G. E. Grau, J. M. Dayer, L. P. Roux, and P. H. Lambert. 1988. Tumor necrosis factor and interleukin-1 in the serum of children with severe infectious purpura. $N$. Engl. J. Med. 319:397-400.

7. de Man, P., C. van Kooten, L. Aarden, I. Engberg, H. Linder, and C. Svanborg Eden. 1989. Interleukin-6 induced at mucosal surfaces by gram-negative bacterial infection. Infect. Immun. 57:3383-3388.

8. Hedges, S., P. Anderson, G. Lidin-Janson, P. de Man, and C. Svanborg. 1991. Interleukin-6 response to deliberate colonization of the human urinary tract with gram-negative bacteria. Infect. Immun. 59:421-427.

9. Barnes, P. F., S. Fong, P. J. Brennan, P. E. Twomey, A. Mazumder, and R. L. Modlin. 1990. Local production of tumor necrosis factor and IFN- $\gamma$ in tuberculous pleuritis. J. Immunol. 145:149-154.

10. O'Hanley, P., D. Lark, S. Falkow, and G. Schoolnik. 1985. Molecular basis of Escherichia coli colonization of the upper urinary tract in BALB/c mice. Gal-Gal pili immunization prevents Escherichia coli pyelonephritis in the BALB/ c mouse model of human pyelonephritis. J. Clin. Invest. 75:347-360.

11. Schumacher, J. H., A. O'Garra, B. Shrader, A. van Kimmenade, M. W. Bond, T. R. Mosmann, and R. L. Coffman. 1988. The characterization of four monoclonal antibodies specific for mouse IL-5 and development of mouse and human IL-5 enzyme-linked immunosorbent. J. Immunol. 141:1576-1581.

12. Starnes, H. F., M. K. Pearce, A. Tewari, J. H. Yim, J. Zou, and J. S. Abrams. 1990. Anti-IL-6 monoclonal antibodies protect against lethal Escherichia coli infection and lethal tumor necrosis factor- $\alpha$ challenge in mice. J. Immunol. 145:4185-4191.

13. Espevik, T., and J. Nissen-Meyer. 1986. A highly sensitive cell line, WEHI 164 clone 13 , for measuring cytotoxic factor/tumor necrosis factor from human monocytes. J. Immunol. Methods. 95:99-105.

14. Chirgwin, J. M., A. E. Przybyla, R. J. MacDonald, and W. J. Rutter. 1979. Isolation of biologically active ribonucleic acid from sources enriched in ribonuclease. Biochemistry. 18:5294-5299.

15. Krug, M. S., and S. L. Berger. 1987. First-strand cDNA synthesis primed with oligo(dT). Methods Enzymol. 152:316-325.

16. Saiki, R. K., D. H. Gelfand, S. Stoffel, S. J. Scharf, R. Higuchi, G. T. Horn, K. B. Mullis, and H. A. Erlich. 1988. Primer-directed enzymatic amplification of DNA with a thermostable DNA polymerase. Science (Wash. DC). 239:487-491.

17. Murray, L. J., R. Lee, and C. Martens. 1990. In vivo cytokine gene expression in T cell subsets of the autoimmune MRL/Mp-lpr/lpr mouse. Eur. J. Immunol. 20:163-170. 
18. O'Garra, A., G. Stapleton, V. Dhar, M. Pearce, J. Schumacher, H. Rugo, D. Barbis, A. Stall, J. Cupp, K. Moore, P. Vieira, T. Mosmann, A. Whitmore, L. Arnold, G. Haughton, and M. Howard. 1990. Production of cytokines by mouse B cells. B lymphomas and normal B cells produce IL-10. Int. Immunol. 2:821832.

19. Brown, K. D., S. M. Zurawski, T. R. Mosmann, and G. Zurawski. 1989. A family of small inducible proteins secreted by leukocytes are members of a new superfamily that includes leukocyte and fibroblast-derived inflammatory agents, growth factors, and indicators of various activation processes. J. Immunol. 142:679-687.

20. Moore, K., P. Vieira, D. F. Fiorentino, M. L. Trounstine, T. A. Khan, and T. R. Mosmann. 1990. Homology of mouse cytokine synthesis inhibitory factor (IL-10) to Epstein-Barr virus gene BCRF1. Science (Wash. DC). 248:1230-1233.

21. Fiorentino, D. F., M. W. Bond, and T. R. Mosmann. 1989. Two types of mouse helper $\mathrm{T}$ cell IV. Th2 clones secrete a factor that inhibits cytokine production by Th1 clones. J. Exp. Med. 170:2081-2095.

22. Bishop, G. A., B. M. Hall, G. G. Duggin, J. S. Horvath, J. Philips, and D. J. Tiller. 1986. Immunopathology of renal allograft rejection analyzed with monoclonal antibodies to mononuclear cell markers. Kidney Int. 29:708-712.

23. McCall, J. L., K. Yun, S. Funamoto, and B. R. Parry. 1989. In vivo immunohistochemical identification of tumor necrosis factor/cachectin in human lymphoid tissue. Am. J. Pathol. 135:421-425.

24. Jutila, M. A., F. G. M. Kroese, K. Jutila, A. M. Stall, S. Fiering, L. A. Herzenberg, E. L. Berg, and E. C. Butcher. 1988. Ly-6C is a monocyte/macrophage and endothelial cell differentiation antigen regulated by interferon-gamma. Eur. J. Immunol. 18:1819-1826.

25. Fong, Y., K. J. Tracey, L. L. Moldawer, D. G. Hesse, K. B. Manogue, J. S. Kenney, A. T. Lee, G. C. Kuo, A. C. Allison, S. F. Lowry, and A. Cerami. 1989. Antibodies to cachectin/tumor necrosis factor reduce interleukin 1 beta and interleukin 6 appearance during lethal bacteremia. J. Exp. Med. 170:1627-1633.

26. Troutt, A. B., and F. Lee. 1989. Tissue distribution of murine hemopoietic growth factor mRNA production. J. Cell Physiol. 138:38-44.

27. Guerne, P. A., B. L. Zuraw, J. A. Vaughan, D. A. Carson, and M. Lotz. 1989. Synovium as a source of interleukin 6 in vitro. J. Clin. Invest. 83:585-592.

28. Lovett, D. H., M. Szamel, J. L. Ryan, R. B. Sterzel, D. Gemsa, and K. Resch. 1986. Interleukin 1 and the glomerular mesangium. I. Purification and characterization of a mesangial cell-derived autogrowth factor. J. Immunol. 136:3700-3705.

29. Budde, K., D. Coleman, J. Lacy, and R. B. Sterzel. 1989. Rat mesangial cells produce granulocyte-macrophage colony-stimulating factor. Am. J. Physiol. 257:F1065-F1078.

30. Baud, L. J. Oudinet, M. Bens, L. Noe, M. Peraldi, E. Rondeau, J. Etienne, and R. Ardaillou. 1989. Production of tumor necrosis factor by rat mesangial cells in response to bacterial lipopolysaccharide. Kidney Int. 35:1111-1118.

31. Horii, Y., A. Muraguchi, M. Iwano, T. Matsuda, T. Hirayama, H. Yamada, Y. Fujii, K. Dohi, H. Ishikawa, Y. Ohmoto, K. Yoshizaki, T. Hirano, and T. Kishimoto. 1989. Involvement of IL-6 in mesangial proliferative glomerulonephritis. J. Immunol. 143:3949-3955.

32. Lovett, D. H., J. L. Ryan, and R. B. Sterzel. 1983. Stimulation of rat mesangial cell proliferation by macrophage interleukin 1 . J. Immunol. 131:28303836.

33. Hedges, S., H. Linder, P. de Man, and C. Svanborg Eden. 1990. Cyclosporin-dependent, nu-independent, mucosal interleukin 6 response to gram-negative bacteria. Scand. J. Immunol. 31:335-343.

34. Linder, H., I. Engberg, C. van Kooten, P. de Man, and C. Svanborg-Eden. 1990. Effects of anti-inflammatory agents on mucosal inflammation induced by infection with gram-negative bacteria. Infect. Immun. 58:2056-2060.

35. Havell, E. A., and P. B. Sehgal. 1991. Tumor necrosis factor-independent IL-6 production during murine listeriosis. J. Immunol. 146:756-761.

36. Sherry, B., P. Tekamp-Olson, C. Gallegos, D. Bauer, G. Davatelis, S. D. Wolpe, F. Masiarz, D. Coit, and A. Cerami. 1988. Resolution of the two components of macrophage inflammatory protein 1 , and cloning and characterization of one of those components, macrophage inflammatory protein $1 \beta . J$. Exp. Med. 168:2251-2259.

37. Davatelis, G., P. Tekamp-Olson, S. D. Wolpe, K. Hermsen, C. Luedke, C. Gallegos, D. Coit, J. Merryweather, and A. Cerami. 1988. Cloning and characterization of a cDNA for murine macrophage inflammatory protein (MIP), a novel monokine with inflammatory and chemokinetic properties. J. Exp. Med. 167:1939-1944.

38. Wolpe, S. D., and A. Cerami. 1989. Macrophage inflammatory proteins and 2: members of a novel superfamily of cytokines. FASEB (Fed. Am. Soc. Exp. Biol.) J. 3:2565-2573. 